\title{
EFISIENSI ANGKA PENGANGGURAN MELALUI LULUSAN SMK DENGAN SISTEM PENDIDIKAN BERKARAKTER ( Enabler, Builders dan Engineer) DI JAWA TIMUR
}

\author{
*( Titin \\ Fakultas Ekonomi \\ Universitas Islam Lamongan
}

\begin{abstract}
ABSTRAK
Sekolah Menengah Kejuruan adalah salah satu tempat belajar formal yang di anggap mampu mengatasi masalah seperti yang di sebutkan di atas oleh orang tua murid, karena telah banyak orang tua murid yang mempecayakan anaknya untuk masuk di Sekolah Menengah Kejuaruan (SMK) setelah lulus dari Sekolah Menengah Pertama. Selain di suguhi ilmu secara teori, di SMK juga langsung bisa mempraktekkan ilmu yang di dapat. Dengan demikian, dengan bertambah banyaknya Sekolah Menengah Kejuruan yang bermunculan di Indonesia di harap bisa merubah karakter generasi muda \& karakter bangsa supaya lebih baik lagi. Di samping itu juga bagaimana SMK bisa mengurangi angka pengangguran dan memperbaiki pembangunan di Jawa Timur.

Mengacu pada rumusan masalah yang akan di urai melalui karya tulis ini tidak lepas dari ruang lingkup permasalahan di atas, yaitu Bagaimana menumbuhkan \& menyiapkan pendidikan karakter generasi muda dengan banyaknya tantangan di era globalisasi, Seberapa besarkah pengaruh \& pentingnya pendidikan karakter di Sekolah Menengah Kejuruan, dan Bagaimana mengatasi pengangguran yang semakin bertambah sehingga memperlambat laju pertumbuhan \& pembangunan bangsa melalui lulusan Sekolah Menengah Kejuruan.

Berdasarkan permasalahan yang telah urai di atas, penulis mempunyai beberapa tujuan, salah satunya adalah Menumbuhkan jiwa generasi muda yang berkarakter, Meningkatkan semangat generasi muda melalui pendidikan karakter, Menciptakan lulusan SMK yang siap bersaing di dunia kerja dan tidak menganggur serta mengurangi angka pengangguran di Jawa Timur dengan adanya pendidikan karakter di SMK.
\end{abstract}

Kata Kunci : Pengangguran, Lulusan SMK, Pendidikan Berkarakter

\section{LATAR BELAKANG MASALAH}

Generasi muda adalah generasi yang belum tua baik dari segi fisik, mental, maupun pikiran. Generasi Inilah yang akan menentukan nasib suatu bangsa. Itu sebabnya karakter generasi muda harus dibentuk dengan semangat juang bela Negara dan cinta tanah air.

Sedangkan pendidikan sendiri adalah elemen penting dalam pembangunan bangsa karena melalui 
pendidikan dasar pembangunan karakter manusia dan bangsa dimulai. Untuk memperbaiki karakter bangsa, akan sangat susah jika memulai dari tengah atau dari atas. Jadi, tindakan tersebut harus dimulai dari awal yaitu dari generasi muda.

Tetapi sungguh kita rasakan keprihatinan yang mendalam tentang kisah anak muda zaman sekarang. Ada penurunan tingkat kualitas generasi muda yang sudah merambah baik dari aspek moralitas, keagamaan, sosial, spiritual dan ideologis. Kasuskasus perkelahian antar pelajar, maraknya penggunaan narkoba, pergaulan bebas, konsumerisme, hilangnya rasa kesantunan anak muda, kriminalitas remaja dan sihir radikalisme terhadap anak muda. Dengan adanya pemberitaan tawuran pelajar, kriminalitas pemuda, dan pergaulan bebas anak itu sangat membuat resah semua orang baik orangtua, guru, supir, petani, bahkan pemerintah Negara. Hal tersebut membuktikan bahwa Nasib Sebuah Bangsa Ada Di Tangan Generasi Muda Dimana Generasi Muda Cerminan Karakter Bangsa.

Sekolah Menengah Kejuruan adalah salah satu tempat belajar formal yang di anggap mampu mengatasi masalah seperti yang di sebutkan di atas oleh orang tua murid, karena telah banyak orang tua murid yang mempecayakan anaknya untuk masuk di Sekolah Menengah Kejuaruan (SMK) setelah lulus dari Sekolah Menengah Pertama. Selain di suguhi ilmu secara teori, di SMK juga langsung bisa mempraktekkan ilmu yang di dapat. Dengan demikian, dengan bertambah banyaknya Sekolah Menengah Kejuruan yang bermunculan di Indonesia di harap bisa merubah karakter generasi muda \& karakter bangsa supaya lebih baik lagi. Di samping itu juga bagaimana SMK bisa mengurangi angka pengangguran dan memperbaiki pembangunan di Jawa Timur.

\section{PERUMUSAN MASALAH}

Mengacu pada uraian latar belakang di atas, maka rumusan pokok permasalahan Karya Tulis Ilmiah Mahasiswa ini dijabarkan sebagai berikut :

1. Bagaimana menumbuhkan \& menyiapkan pendidikan karakter generasi muda dengan banyaknya tantangan di era globalisasi ?

2. Seberapa besarkah pengaruh dan pentingnya pendidikan karakter di Sekolah Menengah Kejuruan?

3. Bagaimana mengatasi pengangguran yang semakin bertambah sehingga memperlambat laju pertumbuhan \& pembangunan bangsa melalui lulusan Sekolah Menengah Kejuruan?

\section{TUJUAN}

Ada beberapa tujuan yang ingin kami capai dari pembuatan Karya Tulis Ilmiah Mahasiswa ini, salah satunya adalah :

1. Menumbuhkan jiwa generasi muda yang berkarakter 
2. Meningkatkan semangat generasi muda melalui pendidikan karakter

3. Menciptakan lulusan SMK yang siap bersaing di dunia kerja dan tidak menganggur

4. Mengurangi angka pengangguran di Jawa Timur dengan adanya pendidikan karakter di SMK

\section{MANFAAT}

Kegunaan

Program

Kreativitas Mahasiswa dalam bidang Kewirausahaan ini adalah :

1. Menghasilkan lulusan Sekolah Menengah Kejuruan yang berpotensi dalam dunia usaha

2. Mengembangkan kreativitas pelajar melalui pendidikan di SMK

3. Menciptakan generasi muda yang siap bersaing di era globalisasi
4. Menaikkan citra SMK yang masih banyak di pandang sebelah mata

5. Menciptakan generasi muda yang siap berwirausaha dan membuka lapangan pekerjaan bagi masyarakat 6. Mengurangi jumlah pengangguran dan turut serta memperbaiki pembangunan di Jawa Timur dengan lulusan SMK.

\section{BATASAN}

Dalam Karya Tulis Ilmiah Mahasiswa Ini hanya membahas terkait pendidikan di Sekolah Menengah Kejuruan dan bagaimana SMK bisa menjadi solusi masa depan dalam mengurangi angka pengangguran \& turut serta dalam memperbaiki pembangunan di Jawa Timur . Dan tidak keluar dari pokokpokok bahasan yang ada. 


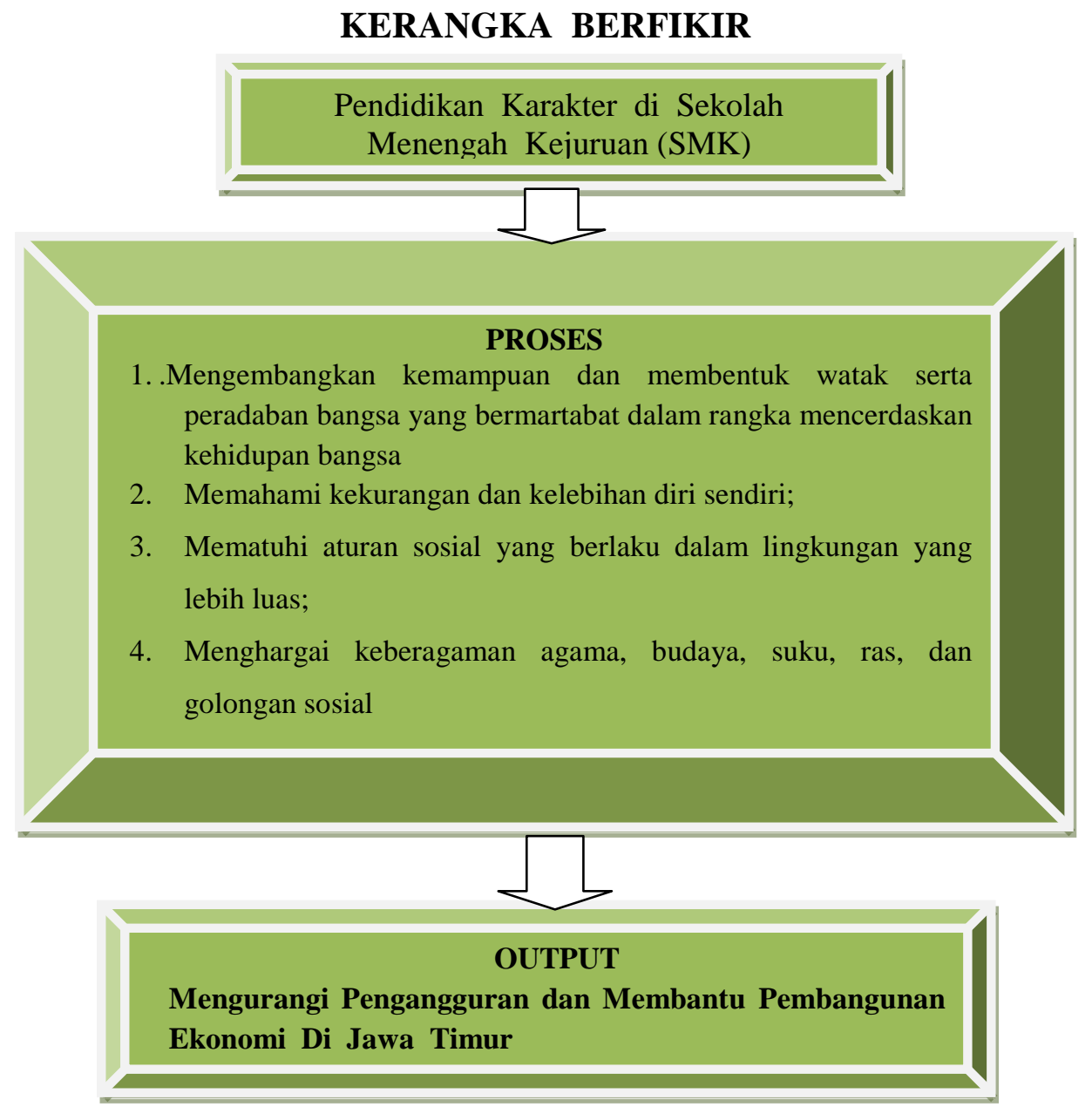

\section{PEMBAHASAN}

A. Menumbuhkan dan menyiapkan karakter generasi muda

Harus diakui bahwa sorotan terhadap karakter bangsa saat ini telah semakin mengemuka, Pemerintah semakin gencar mengkampenyekan pendidikan karakter di sekolah setidaknya dapat merubah tingkah laku pelajar agar bertata krama yang lebih baik, mempunyai budi pekerti yang luhur dari sebelumnya.

Tampaknya tidak berlebihan jika bangsa Indonesia tidak terlepas dari fenomena globalisasi selama ini digambarkan sebagai bangsa yang mengalami penurunan kualitas karakter bangsa. Karakter bangsa yang dimaksudkan adalah keseluruhan sifat yang mencakup perilaku, kebiasaan, kesukaan, kemampuan, bakat, potensi, nilainilai, dan pola pikir yang dimiliki oleh sekelompok manusia yang mau bersatu, merasa dirinya bersatu, memiliki kesamaan nasib, asal, keturunan, bahasa, adat dan sejarah bangsa. Sekurangkurangnya ada 17 nilai karakter bangsa yang diharapkan dapat dibangun oleh bangsa Indonesia. Adapun nilai-nilai karakter bangsa yang dimaksud adalah iman, taqwa, berakhlak mulia, berilmu/berkeahlian, jujur, disiplin, demokratis, adil, bertanggung jawab, cinta tanah air, orientasi pada keunggulan, gotong-royong, 
sehat, mandiri, kreatif, menghargai dan cakap. Pembangunan karakter bangsa adalah upaya sadar untuk memperbaiki, meningkatkan seluruh perilaku yang mencakup adat istiadat, nilai-nilai, potensi, kemampuan, bakat dan pikiran bangsa Indonesia.

Semangat untuk menjadi bangsa yang berkarakter ditegaskan oleh Soekarno dengan mencanangkan nation and character building dalam rangka membangun dan mengembangkan karakter bangsa Indonesia guna mewujudkan cita-cita bangsa, yaitu masyarakat yang adil dan makmur berdasarkan Pancasila. Secara spesifik Soekarno menegaskan dalam amanat Pembangunan Semesta Berencana tentang pentingnya karakter ini sebagai mental investment, yang mengatakan bahwa kita jangan melupakan aspek mental dalam pelaksanaan pembangunan dan mental yang dimaksud adalah mental Pancasila.

Sekolah sebagai institusi pendidikan tempat menempah moral bangsa sebaiknya memiliki komitmen untuk membangun karakter bangsa. Pendidikan karakter dimaksudkan untuk mengembangkan kemampuan dan membentuk watak serta peradaban bangsa yang bermartabat dalam rangka mencerdaskan kehidupan bangsa. Secara lebih khusus pendidikan karakter memiliki tiga fungsi utama, yaitu :

1.Pembentukan dan pengembangan

Potensi pendidikan karakter berfungsi membentuk dan mengembangkan potensi manusia atau warga Negara Indonesia agar berpikiran baik, berhati baik, dan berperilaku baik sesuai dengan falsafah hidup Pancasila

2.Perbaikan dan Penguatan

Pendidikan karakter berfungsi memperbaiki karaker manusia dan warga Negara Indoneisa yang bersifat negative dan memperkuat peran keluarga, satuan pendidikan, masyarakat, dan pemerintah untuk ikut berpartisipasi dan bertanggung jawab dalam pengembangan potensi manusia atau warga Negara menuju bangsa yang berkarakter, maju, mandiri dan sejahtera.

3.Penyaring

Pendidikan karakter bangsa berfungsi memilah nilai-nilai budaya bangsa sendiri dan menyaring nilai-nilai budaya bangsa lain yang positif untuk menjadi karakter manusia dan warga Negara Indonesia agar menjadi bangsa yang bermartabat Pendidikan karakter meliputi dan berlangsung pada :

- Pendidikan Formal

Pendidikan karakter pada pendidikan formal berlangsung pada lembaga pendidikan TK/RA, SD/MI, SMP/MTs, SMA/MA, SMK, MAK dan Perguruan Tinggi melalui pembelajaran, ekstrakurikuler, penciptaan budaya satuan pendidikan, dan pembiasaan. Sasaran pada pendidikan formal adalah peserta didik, pendidik, dan tenaga kependidikan.

- Pendidikan Nonformal

Pendidikan karakter berlangsung pada lembaga kursus, pendidikan kesetaraan, pendidikan keaksaraan, dan lembaga pendidikan nonformal lain melalui pembelajaran, penciptaan budaya satuan 
pendidikan, dan pembiasaan. Sasaran pada pendidikan nonformal adalah peserta didik, pendidik, dan tenaga kependidikan.

- Pendidikan Informal

Pendidikan karakter pada pendidikan informal berlangsung pada keluarga yang dilakukan oleh orangtua dan orang dewasa lain terhadap anak-anak yang menjadi tanggungjawabnya.

- Pendidikan Informal

Pendidikan karakter pada pendidikan informal berlangsung pada keluarga yang dilakukan oleh orangtua dan orang dewasa lain terhadap anak-anak yang menjadi tanggungjawabnya.

Dalam pendidikan, membangun karakter bangsa mencakup upaya untuk mencapai suatu proses internalisasi pengetahuan yang kemudian dapat berlanjut sampai dengan terjadinya suatu perubahan. Dalam dunia pendidikan, keberhasilan pendidikan bukan diukur dari tercapainya target akademis siswa, tetapi lebih kepada proses pembelajaran sehingga dapat memberikan perubahan sikap dan perilaku kepada siswa.

Karakter bangsa ini ditentukan oleh pelajar kita nantinya. Seluruh komponen bangsa juga turut mendukung upaya pembangunan karakter ini. Upaya Pembangunan karakter ini dapat ditentukan oleh faktor internal dan faktor eksternal. Dari Faktor internal adalah kemauan pelajar untuk membentuk karakter positif pada dirinya sendiri, apalagi jika dilakukan sejak usia dini. Sedangkan faktor eksternal meliputi sekolah, lingkungan, ekonomi, tayangan televisi, pendidikan yang tidak berkualitas, dan lain-lain.

Karakter bangsa yang kuat sangat diperlukan, maka dituntut peran penting dari generasi muda, khususnya perannya sebagai character enabler, character builders dan character engineer. Tiga peran itu adalah :

1. Sebagai Pembangun kembali karakter bangsa (Character builder).

Di tengah-tengah derasnya arus globalisasi, peran ini tentunya sangat berat, namun esensinya adalah adanya kemauan keras dan komitmen dari generasi muda untuk menjunjung nilai-nilai moral untuk menginternalisasikannya pada aktifitas sehari-hari.

2. Sebagai Pemberdaya karakter (Character enabler)

Peran ini juga tidak kalah beratnya, selain kemauan kuat dan kesadaran kolektif dengan kohesivitas tinggi, masih dibutuhkan adanya kekuatan untuk terlibat dalam masyarakat maupun di tempat asing.

3. Sebagai perekayasa karakter (Character engineer)

Peran ini menuntut generasi muda untuk terus melakukan pembelajaran, adanya modifikasi dan rekayasa yang tepat disesuaikan dengan perkembangan zaman. Peran generasi muda dalam hal ini sangat diharapkan oleh bangsa, karena ditangan merekalah proses pembelajaran adaptif dapat berlangsung dalam kondisi yang paling produktif.

Menghadapi globalisasi, karakter generasi muda harus lebih meningkatkan pembangunan budi pekerti dan sikap menghormati dan 
harus mengaplikasikannya dalam kehidupan sehari-hari. Menteri Pendidikan Nasional, Mohammad Nuh menegaskan, bahwa "tidak ada yang menolak tentang pentingnya karakter, tetapi yang lebih penting adalah bagaimana menyusun dan menyistemasikan, sehingga anak-anak dapat lebih berkarakter dan lebih berbudaya".Meskipun begitu generasi muda nantinya masih memerlukan dukungan dari pemerintah maupun komponen bangsa lainnya, namun esensi utamanya tetap pada peran generasi muda. Hal tersebut selain karena generasi muda masih berada dalam puncak produktifitasnya, juga karena generasi muda adalah komponen bangsa yang paling strategis posisinya dalam memainkan proses transformasi karakter dan tata nilai di tengahtengah derasnya liberalisasi informasi era globalisasi.

\section{B. Penerapan Dan Pengaruh Pendidikan Karakter di SMK}

Pendidikan karakter dapat diintegrasikan dalam pembelajaran pada setiap mata pelajaran. Materi pembelajaran yang berkaitan dengan norma atau nilai-nilai pada setiap mata pelajaran perlu dikembangkan, dieksplisitkan, dikaitkan dengan konteks kehidupan sehari-hari. Dengan demikian, pembelajaran nilai-nilai karakter tidak hanya pada tataran kognitif, tetapi menyentuh pada internalisasi, dan pengamalan nyata dalam kehidupan peserta didik sehari-hari di masyarakat.

Oleh karena itu, pendidikan karakter siswa SMK sangat penting, diantaranya dengan mengadakan ekstrakurikuler dan bimbingan konseling (selain dari pendidikan agama), yang selama ini memang sudah diselenggarakan sekolah. Kegiatan ekstrakulikuler ini merupakan salah satu media yang potensial untuk pembinaan karakter, kemampuan, rasa tanggung jawab sosial, bekerja sama, menghargai orang lain, serta mengembangkan potensi dan prestasi peserta didik. Peningkatan mutu akademik peserta didik dengan kegiatan ekstrakurikuler merupakan kegiatan pendidikan di luar mata pelajaran untuk membantu pengembangan peserta didik sesuai dengan kebutuhan, potensi, bakat, dan minat mereka melalui kegiatan yang secara khusus diselenggarakan oleh pendidik atau tenaga kependidikan yang berkemampuan dan berkewenangan di sekolah.

Selain itu, Bimbingan dan Konseling (BK) juga merupakan bagian penting dalam pembentukan karakter siswa SMK, dimana BK ini sebagai media pengarah dan pembimbing siswa mempunyai tujuan untuk mendorong: perkembangan karir serta kehidupan-nya di masa yang akan datang, mengembangkan seluruh potensi dan kekuatan yang dimilikinya seoptimal mungkin, menyesuaikan diri dengan lingkungan pendidikan, lingkungan masyarakat serta lingkungan kerjanya, mengatasi hambatan dan kesulitan yang dihadapi dalam studi, penyesuaian dengan lingkungan pendidikan, masyarakat, maupun lingkungan kerja. Jadi sangat jelas bahwa BK merupakan salah satu komponen yang sangat penting didalam dunia pendidikan sebagai salah satu yang 
dapat mendorong pembentukan karakter yang baik pada siswa.

Pendidikan karakter di sekolah juga sangat terkait dengan manajemen atau pengelolaan sekolah. Pengelolaan yang dimaksud adalah bagaimana pendidikan karakter direncanakan, dilaksanakan, dan dikendalikan dalam kegiatankegiatan pendidikan di sekolah secara

memadai. Pengelolaan tersebut antara lain meliputi, nilai-nilai yang perlu ditanamkan, muatan kurikulum, pembelajaran, penilaian, pendidik dan tenaga kependidikan, dan komponen terkait lainnya. Dengan demikian, manajemen sekolah merupakan salah satu media yang efektif dalam pendidikan karakter di sekolah.

Keberhasilan program pendidikan karakter dapat diketahui melalui pencapaian indikator oleh peserta didik sebagaimana tercantum dalam Standar Kompetensi Lulusan SMK, yang antara lain meliputi sebagai berikut:

1) Dapat menjadi lulusan yang mampu bersaing, dan dapat menjadi pekerja teknologi tingkat menengah

2) Memiliki jiwa kewirausahaan, bahkan dapat melakukan wirausaha

3) Mengamalkan ajaran agama yang dianut sesuai dengan tahap perkembangan remaja;

4) Memahami kekurangan dan kelebihan diri sendiri;

5) Menunjukkan sikap percaya diri;

6) Mematuhi aturan sosial yang berlaku dalam lingkungan yang lebih luas;
7) Menghargai keberagaman agama, budaya, suku, ras, dan golongan sosial

ekonomi dalam lingkup nasional;

8) Mencari dan menerapkan informasi dari lingkungan sekitar dan sumber-

sumber lain secara logis, kritis, dan kreatif;

9) Menunjukkan kemampuan berpikir logis, kritis, kreatif, dan inovatif;

10) Menunjukkan kemampuan belajar secara mandiri sesuai dengan potensi

yang dimilikinya;

Karakter siswa SMK berbasis pada dimensi moral, dimensi nilainilai dan dimensi kepribadian kejuruan. Karakter siswa dapat dibentuk melalui program-program sekolah. Evaluasi karakter siswa dapat dinilai melalui indikator kejujuran, rasa hormat, tanggung jawab, kewajaran, kepedulian, dan kewarganegaraan. Indikator karakter dapat dikelompokan atas dimensi jenis dan dimensi proaktif. Dimensi kepribadan kejuruan merupakan basis penentuan kesesuaian karakter siswa dengan karakter lingkungan kerja. Pengembangan program dan instrumen penilaian karakter dikembangkan melalui tahapantahapan, dan ada berbagai macam alat evaluasi karakter siswa. Lembaga pendidikan dapat membentuk karakter siswa, baik di kelas oleh guru maupun di sekolah oleh pimpinan dan programnya. Lembaga pendidikan baik di tingkat makro dan mikro bertanggung jawab terhadap pembentukan karakter siswa.

Pembentukan karakter siswa SMK salah satunya dengan perlu 
dipertimbangkannya kepribadian kejuruan. Sebab kesesuaian karakter siswa dengan lingkungan praktek (kerja) siswa akan meningkatkan karakter positif seorang siswa SMK. Pembentukan karakter siswa SMK berbeda dengan sekolah umum (SMA atau MAN), karena faktor lingkungan kerja (praktek) besar perannya dalam pembentukan karakter siswa SMK.

Dengan adanya sistem kurikulum KTSP (kurikulum tingkat satuan pendidikan) akan membuka peluang yang sangat besar untuk sekolah supaya dapat mengembangkan pendidikan pembentukan karakter. Sehingga dapat dicari media seperti apakah dan pembelajaran seperti apa yang cocok untuk anak SMK.

\section{Pengaruh SMK Terhadap Angka Pengangguran di Jawa Timur}

Tingkat pengangguran di Jawa Timur diperkirakan mencapai 1,2 juta. Hal ini seiring dengan banyaknya lulusan SMA dan sederajat yang masih belum mendapatkan pekerjaan.

Kadisnakertransduk akan berusaha untuk menurunkan tingkat pengangguran tersebut. Kadisnakertransduk optimistis pada 2013 mendatang, penganguran akan turun menjadi 300 ribu orang.

Langkah yang akan dilakukan adalah dengan mengoptimalkan kinerja Balai Latihan Kerja (BLK), pameran kerja, transmigrasi hingga kerja sama dengan daerah lain untuk pengiriman tenaga kerja Indonesia (TKI).

Terlebih lagi saat ini Pemprov Jatim membuka peluang kerja untuk menjadi pegawai negeri sipil
(PNS). Sebab pemberlakukan moratarium PNS hanya berlaku sampai 2012 saja.

Keterserapan alumni SMK dalam pasar tenaga kerja berarti penciptaan income bagi alumni SMK, sekaligus pendapatan bagi daerah (dalam bentuk PDRB) di mana alumni tersebut bekerja. Peran inilah yang kemudian menjadikan SMK menjadi suatu engine sector of growth dalam pertumbuhan ekonomi di daerah.

Untuk memperoleh SDM yang berkualitas dan memiliki daya saing, perlu didukung oleh suatu sistem pendidikan dan pelatihan nasional yang dikembangkan berdasar pada kebutuhan pasar kerja dan dinamika percepatan perubahan yang terjadi pada dunia usaha dan dunia industri.

Pemerintah Indonesia (dengan kesepakatan antara Departemen Tenaga Kerja dan Transmigrasi dan Departemen Pendidikan Nasional, sebagaimana yang dirilis oleh Bapekki Depkeu melalui harian Bisnis Indonesia tanggal 20 Maret 2007), menunjukkan komitmennya atas reformasi sistem pendidikan di negeri ini. Komitmen ini diterapkan pada tahun ini dengan dengan mengubah fokus pendirian lembaga Pendidikan. Lembaga-lembaga pendidikan yang bersifat kejuruan akan diperbanyak jumlahnya. Idealnya, menurut Bapekki jumlah lembaga pendidikan kejuruan mencapai $70 \%$ darl lembaga pendidikan yang ada, sedangkan sisanya $30 \%$ lagi diisi oleh lembaga pendidikan umum. Komposisi ini telah banyak diterapkan oleh negara-negara di kawasan Asia dan Eropa, dan telah terbukti mampu menekan laju pengangguran di negara-negara tersebut. Dengan 
besamya komposisi lembaga pendidikan kejuruan, akan tercipta link and match antara dunia pendidikan dan lulusannya dengan kebutuhan tenaga kerja di dunia usaha.. Jika ketrampilan dan kemampuan untuk memproduksi meningkat maka pertumbuhan ekonomi pun akan meningkat. Dengan alasan inilah SMK merupakan lembaga pendidikan yang mempersiapkan lulusannya untuk memiliki pengetahuan, keahlian, dan ketrampilan yang akan menjadi bekal setelah menyelesaikan pendidikan. Sehingga lulusan SMK memiliki bekal sebagai job creator maupun sebagai worker, yang berarti siap memasuki pasar kerja. Pendidikan Menengah Kejuruan mengantisipasi kondisi ini melalui penerapan sistem pendidikan dan pelatihan Kejuruan berdasarkan kompetensi (CBT).

Dengan pemikiran ini, pembahasan tentang peran pendidikan SMK terhadap pertumbuhan perekonomian akan melibatkan pembahasan SMK sebagai lembaga yang menyiapkan specific human capital yang berkualitas. Dengan terciptanya SDM/lulusan yang berkualitas yaitu lulusan yang cerdas, terampil dan siap kerja sehingga siap memasuki pasar kerja. Keterserapan para lulusan yang merupakan output SMK akan meningkatkan produktivitas yang pada gilirannya akan meningkatkan pertumbuhan ekonomi melalui terciptanya nilai tambah terhadap barang dan jasa yang terdapat dalam dijelaskan dengan tingkat partisipasi masyarakat dalam menyekolahkan anak-anaknya untuk menempuh studi di jenjang SMK. Semakin tinggi tingkat partisipasi masyarakat, semakin tinggi pula kualitas SDM yang dapat digunakan dalam pengolahan sumber daya yang tersedia dalam perekonomian.

Ini berarti penyediaan sekolah kejuruan untuk mencetak necessary skills menjadi sangat penting. Meminjam istilah Becker (1964), SMK merupakan lembaga pendidikan yang dimaksudkan untuk menghasilkan specific human capital.

DATA BPS TINGKAT PENGANGGURAN TERBUKA PADA USIA PRODUKTIF

\begin{tabular}{|l|l|l|}
\hline $\begin{array}{l}\text { TINGKATAN } \\
\text { PENDIDIKAN }\end{array}$ & FEBRUARI 2014 & FEBRUARI 2015 \\
\hline UNIVERSITAS & $4,31 \%$ & $5,34 \%$ \\
\hline DIPLOMA & $5,87 \%$ & $7,49 \%$ \\
\hline SMK & $7,21 \%$ & $9,05 \%$ \\
\hline \multicolumn{2}{|c|}{} & \\
\hline \multicolumn{2}{|c|}{ Jumlah 909.368 } & 740.091
\end{tabular}

*) sumber data BPS Jatim Per Februari 2014-2015

http://bisniskeuangan.kompas.com/read/2015/05/05/211900126/Makin.Banyak .Sarjana.Diploma.dan.Lulusan.SMK.yang.Menganggur 
Berdasarkan data BPS diatas menunjukkan bahwa prosentase pengangguran SMK lebih kecil dibanding dengan tingkat pendidikan yang lain. Ini menunjukkan SMK berpengaruh terhadap angka pengangguran di jawa timur.

\section{KESIMPULAN}

Dari uraian terkait pengaruh lulusan smk terhadap angka pengangguran dan pembangunan di jawa timur tersebut, dapat di simpulkan sebagai berikut :

1. Pendidikan merupakan wahana yang tepat untuk menumbuhkembangkan

karakter bangsa yang baik. Melalui Pendidikan dapat membangun karakter generasi muda dalam menghadapi era globalisasi. Karena di dalam pendidikan ada proses pembelajaran yang pada akhirnya diharapkan terjadi transformasi yang dapat menumbuhkembangkan karakter positif, serta mengubah watak dari yang tidak baik menjadi baik.

2 Sekolah Menengah Kejuruan Merupakan salah satu alternatif tempat formal pendidikan berkarakter yang mampu menjadi salah satu solusi dalam mengurangi pengangguran di Jawa Timur

\section{SARAN}

1. Membangun karakter bangsa melalui pendidikan diharapkan menjadi kegiatankegiatan diskusi, simulasi, dan penampilan berbagai kegiatan sekolah untuk itu pendidik diharapkan lebih aktif dalam pembelajarannya.

2. Dengan adanya pendidikan karakter di Sekolah Menengah Kejuruan di harapkan bisa lebih meningkatkan kualitas atau lulusan yang bisa menciptakan lapangan pekerjaan sendiri dan bisa mengurangi angka pengangguran serta bisa mewujudkan pembangunan yang baik di Jawa Timur.

\section{DAFTAR PUSTAKA}

Membangun Karakter dan Kemandirian Bangsa. http://www.setneg.go.id

(diakses tanggal 14 November 2012)

Membangun Karakter Generasi

Muda.

http://www.beritaindonesia.co.id

(diakses 14 November 2012)

Kondisi Moral Bangsa Sangat

Mengkhawatirkan.

http://www.jpnn.com

(diakses tanggal14 November 2012)

http://www.jatimprov.go.id/site/ko ndisi-ketenagakerjaan-di-jatimkondusif- dorong-penciptaanpeluang-kerja/

.Tim Pengembang MKDP. (2006). Materi Perkuliahan Kurikulum dan Pembelajaran. Bandung: FIP UPI (2010). Tujuan Pelayanan Bimbingan dan Konseling. [online]. Tersedia: http://akhmadsudrajat.wordpress. com/2008/03/14/tujuanbimbingan-dan-konseling/. 